ISSN 1392-3196 / e-ISSN 2335-8947

Zemdirbyste-Agriculture, vol. 102, No. 4 (2015), p. 381-388

DOI $10.13080 / \mathrm{z}-\mathrm{a} .2015 .102 .048$

\title{
The effect of fertilizer and $\mathrm{N}$ application rate on nitrogen and potassium leaching in cut grassland
}

\author{
Mailiis TAMPERE, Karin KAUER, Indrek KERES, Evelin LOIT, Are SELGE, \\ Rein VIIRALT, Henn RAAVE \\ Institute of Agricultural and Environmental Sciences, Estonian University of Life Sciences \\ Kreutzwaldi 1A, 51014 Tartu, Estonia \\ E-mail: mailiis.tampere@emu.ee
}

\begin{abstract}
Although fertilization has a positive effect on agricultural productivity, its negative side effect can be the leaching of plant nutrients. Our objectives were to study the impact of fertilizer type and nitrogen application rate on the nitrogen and potassium leaching from grassland during and after the vegetative period. Within three years (20082011) mini-lysimeters experiment was conducted on grassland swards receiving mineral NPK, mineral PK, cattle slurry and sewage sludge based on nitrogen rate $0,60,120$ and $180 \mathrm{~kg} \mathrm{ha}^{-1}$ year $^{-1}$. Nitrogen and potassium leaching was measured monthly throughout the experimental period. From our results it can be concluded that nitrogen leaching is lower with the use of mineral NPK, because it increases the sward yield most efficiently. Potassium leaching in grassland can be reduced when using nitrogen containing fertilizers, as the fertilizer N:K ratio has a great effect on its leaching potential. Fertilizers are not the only $\mathrm{N}$ and $\mathrm{K}$ leaching source. It can be high also from unfertilized soil at the expense of soil reserves. Injection of slurry at rational amounts can be an effective method for the reduction of nitrogen leaching in grassland.
\end{abstract}

Key words: cattle slurry, leaching, nitrogen, nitrogen rate, potassium, sewage sludge.

\section{Introduction}

Advanced use of fertilizers has resulted in significantly increased agricultural productivity, but simultaneously in a higher environmental pressure (Mondelaers et al., 2009), of which contamination of surface and groundwater by plant nutrients is among the most serious (Aronsson et al., 2006; Bergström et al., 2008; Gali et al., 2012). Nutrient leaching is considered the most problematic in regions where precipitation exceeds evaporation considerably. Estonia is located in a moderately cold and humid climate region with annual precipitation exceeding evaporation 1.5-2 times; therefore conditions for nutrient leaching are favourable.

It has been found that the least amount of nitrates leaches into the groundwater when perennial grasses are grown (Adomaitis et al., 2008), as they cover the soil year-round with growing vegetation and grasses are efficient at taking up nitrogen $(\mathrm{N})$ from soil. Still the risk of leaching increases, when $\mathrm{N}$ input exceeds the swards capacity to utilize the available N (Malhi et al., 2002), especially when fertilizers are applied based on agronomically optimal dry matter production amounts without taking into account the economically optimal fertilizer recommendations for different species.

It is assumed that organically farmed systems have lower nutrient losses compared with conventionally farmed systems that rely on soluble fertilizer inputs
(Condron et al., 2000). Bergström et al. (2008) suggest that in organic systems, which depend on renewable and natural fertilizer sources $\mathrm{N}$ mineralization and crop $\mathrm{N}$ demand are poorly synchronized making it more vulnerable to leaching than inorganic fertilizers, especially under the cold and humid climate conditions. Ten Berge et al. (2002) and Schröder et al. (2010) state that it does not matter much from a leaching point-of-view whether the $\mathrm{N}$ requirement is met with mineral fertilizer- $\mathrm{N}$ or with plant-available $\mathrm{N}$ from manure; it is the quantity of $\mathrm{N}$ in the system rather than the source of $\mathrm{N}$, which determines the environmental impact (Watson, Younie, 1995).

Nitrogen fertilizers have been commonly implicated as the main cause of the leaching problem (Kirchmann et al., 2002), but unbalanced fertilization leading to high levels of available potassium $(\mathrm{K})$ in the soil can increase its leaching losses considerably (Kayser, Isselstein, 2005). Although $\mathrm{K}$ is not regarded as a substantial environmental pollutant, it is extremely important as a plant and animal nutrient and therefore needs to be in adequate supply for good grassland systems production (Laegreid et al., 1999). It has even been claimed that $\mathrm{K}$ application can alleviate the $\mathrm{N}$ pollution problem by inducing a high uptake rate of $\mathrm{N}$ by crops (Zhang et al., 2010). Greater K leaching losses have been found from the areas where inorganic fertilizer is used 
when compared to organic nutrient sources (Torstensson et al., 2006), but also that the form of $\mathrm{K}$ supply has no effect on the total $\mathrm{K}$ leaching losses (Alfaro et al., 2004).

A possibility to apply organic matter and nutrients to agricultural land may be fertilization with stabilized sewage sludge from municipal wastewater treatment plants. It can be used as an addition to animal wastes or as a readily available alternative to the use of inorganic fertilizers. It contains useful concentration of nitrogen, phosphorus and potassium and to a lesser extent, calcium, sulphur and magnesium (Usman et al., 2012). Sewage sludge advantages are associated mainly with its influence on crop yield but also with soil properties (Wang et al., 2008). However, similarly to other fertilizers inappropriate application times or rates may lead to poor utilisation by crops and, thus, to nitrate leaching and water contamination (Shepherd, 1996).

A three-year experiment on nutrient leaching was conducted in Estonia to study the impact of (i) fertilizer type and (ii) $\mathrm{N}$ application rate on the amounts of $\mathrm{N}$ and $\mathrm{K}$ leached from the grassland during and after the vegetative period in moderately cold and humid climatic conditions. We hypothesised that $\mathrm{N}$ and $\mathrm{K}$ leaching depends on both fertilizer type and $\mathrm{N}$ rate used.

\section{Materials and methods}

The experiment was conducted from May 2008 to January 2011 at the Eerika Experimental Station, Estonian University of Life Sciences (58 23'32" N, $26^{\circ} 41^{\prime} 31^{\prime \prime} \mathrm{E}$; elevation $60 \mathrm{~m}$ ). Plastic mini-lysimeters with an area of $0.0706 \mathrm{~m}^{-2}$ and $30 \mathrm{~cm}$ depth were used. The construction of lysimeters used in the experiment is described in more detail by Raave et al. (2014). Minilysimeters were filled with loamy sand (64\% sand, 29\% silt, $7 \%$ clay; specific surface area of $\left.30.6 \mathrm{~m}^{-2} \mathrm{~g}^{-1}\right)$.

The experiment was $3 \times 3 \times 4$ factorial design with three replicates. We tested fertilizer effect on three different swards: (i) grasses-only mixture including timothy (Phleum pratense L.), perennial ryegrass (Lolium perenne L.) and smooth meadow-grass (Poa pratensis L.), (ii) the above mentioned grasses mixed with white clover (Trifolium repens L.) and (iii) grasses mixed with lucerne (Medicago sativa L.). Fertilizer treatments were (i) mineral fertilizer, (ii) cattle slurry and (iii) sewage sludge with four different $\mathrm{N}$ application rates $\left(0,60,120\right.$ and $\left.180 \mathrm{~kg} \mathrm{ha}^{-1}\right)$. The grasses-lucerne plot was assessed only in the first and second year, because the experimental conditions were not suitable for lucerne and its percentage in the sward decreased to a minimum after the second year.

The application rates of mineral fertilizers in $\mathrm{kg}$ ha' ${ }^{-1}$ were: $\mathrm{N}_{0} \mathrm{P}_{0} \mathrm{~K}_{0}$ (control), $\mathrm{N}_{0} \mathrm{P}_{30} \mathrm{~K}_{60}, \mathrm{~N}_{0} \mathrm{P}_{60} \mathrm{~K}_{120}, \mathrm{~N}_{60} \mathrm{P}_{30} \mathrm{~K}_{60}$, $\mathrm{N}_{120} \mathrm{P}_{60} \mathrm{~K}_{120}$ and $\mathrm{N}_{180} \mathrm{P}_{60} \mathrm{~K}_{120}$. We used $\mathrm{NH}_{4} \mathrm{NO}_{3}, \mathrm{Ca}\left(\mathrm{H}_{2} \mathrm{PO}_{4}\right)_{2}$ and $\mathrm{KCl}$ as the sources of $\mathrm{N}, \mathrm{P}$ and $\mathrm{K}$, respectively. In this article, we used the average of fertilizer rates $\mathrm{N}_{0} \mathrm{P}_{30} \mathrm{~K}_{60}$ and $\mathrm{N}_{0} \mathrm{P}_{60} \mathrm{~K}_{120}$ under the abbreviation of PK. Organic fertilizers were applied to provide $\mathrm{N}$ rates of 60,120 and $180 \mathrm{~kg} \mathrm{ha}^{-1}$. Their application rate was calculated based on the $\mathrm{NH}_{4}^{+}-\mathrm{N}$ content. Mineral $\mathrm{P}$ and $\mathrm{K}$ fertilizers were not applied with organic manure. All fertilizers were applied to the plots in one to three split applications, depending on the $\mathrm{N}$ rate. Both organic fertilizers were applied manually. Sewage sludge was spread on the sward surface, cattle slurry was applied either by spreading or by injection.

The quantities of leachate water and total $\mathrm{N}$ and $\mathrm{K}$ contents in the water were measured on a monthly basis throughout the year, except in the period when the soil was frozen. Leachate was removed from the lysimeter with a vacuum pump. After the leachate was measured with a beaker, water samples $(20 \mathrm{ml})$ were collected for the determination of $\mathrm{N}$ and $\mathrm{K}$ content in the leachate. The average amounts of leached $\mathrm{N}$ and $\mathrm{K}$ were calculated as follows: (i) average $\mathrm{N}$ or $\mathrm{K}$ leaching of each fertilizer type $\left(\mathrm{g} \mathrm{m}^{-2}\right)=\sum$ leached $\mathrm{N}$ or K amounts $\left(\mathrm{g} \mathrm{m}^{-2}\right)$ in all swards at all $\mathrm{N}$ rates used / the number of measurements, (ii) average $\mathrm{N}$ or $\mathrm{K}$ leaching of each $\mathrm{N}$ rate used $\left(\mathrm{g} \mathrm{m}^{-2}\right)=\sum$ leached $\mathrm{N}$ or $\mathrm{K}$ amounts $(\mathrm{g})$ in all swards in all fertilizer treatments / the number of measurements. The flow-weighted average concentrations of $\mathrm{N}$ and $\mathrm{K}$ in the leachate for each replication of every fertilizer type and $\mathrm{N}$ rate used were calculated as follows: $\sum$ amount of leached $\mathrm{N}$ or $\mathrm{K}\left(\mathrm{g} \mathrm{m}^{-2}\right)$ of each measurement $/ \sum$ amount of percolated water $\left(\mathrm{L} \mathrm{m}^{-2}\right)$ of each measurement. Fisher's least significant difference (LSD) test for homogeneous groups was used for testing the significance of differences between treatments.

A more comprehensive description of the methodology including information about $\mathrm{K}$ amounts applied with organic fertilizers, chemical, statistical and mathematical analyses conducted and meteorological conditions during the experimental period can be found in Tampere et al. (2014).

\section{Results and discussion}

Nitrogen (N) leaching during and after vegetative period depending on fertilizer type used. Fertilizer type had significant $(P<0.05)$ influence on $\mathrm{N}$ leaching during the vegetation period (vegetation period is the part of the year with daily mean temperatures steadily above $\left.+5^{\circ} \mathrm{C}\right)$, April to November. In three-year average the lowest $\mathrm{N}$ leaching $(P<0.05)$ occurred from mineral NPK treatment (Table 1). Between other treatments it was similar. Sward yield was the highest with mineral NPK fertilizer use. Our research shows that water percolation together with nutrient leaching is reduced with increasing yield (Tampere et al., 2014). Similarly to findings by Bergström et al. (2008) this result demonstrates that $\mathrm{N}$ leaching is not lower when using organic fertilizers compared to mineral fertilizers. Several previous studies (Hansen et al., 2000; Knudsen et al., 2006) have found that $\mathrm{N}$ leaching was lower in organic systems and the reason for it was lower $\mathrm{N}$ input. This has been criticized by Kirchmann and Bergström (2001), who argued that equal conditions, such as $\mathrm{N}$ input between organic and conventional farming systems, must be ensured in order to obtain conclusive results. 
Table 1. Average yields and amounts of percolated water, flow-weighted average nitrogen (N) and potassium (K) concentrations in the leachate, and average amounts of leached $\mathrm{N}$ and $\mathrm{K}$ depending on used fertilizer type during and after the vegetative period (averaged for the three-year period)

\begin{tabular}{|c|c|c|c|c|c|c|}
\hline $\begin{array}{l}\text { Fertilizer } \\
\text { type }\end{array}$ & $\begin{array}{l}\text { Dry matter } \\
\text { yield } \\
\mathrm{kg} \mathrm{m}^{-2}\end{array}$ & $\begin{array}{c}\text { Amount of } \\
\text { percolated water } \\
\mathrm{L} \mathrm{m}^{-2}\end{array}$ & $\begin{array}{c}\mathrm{N} \text { content } \\
\text { in leachate } \\
\mathrm{mg} \mathrm{L}^{-1}\end{array}$ & $\begin{array}{c}\mathrm{K} \text { content } \\
\text { in leachate } \\
\mathrm{mg} \mathrm{L}^{-1}\end{array}$ & $\begin{array}{c}\text { Amount of } \\
\text { leached } \mathrm{N} \\
\mathrm{g} \mathrm{m}^{-2}\end{array}$ & $\begin{array}{c}\text { Amount of } \\
\text { leached } \mathrm{K} \\
\mathrm{g} \mathrm{m}^{-2}\end{array}$ \\
\hline \multicolumn{7}{|c|}{ During vegetative period } \\
\hline 0 & $0.44 \mathrm{~A}$ & $113.4 \mathrm{~A}$ & $18.9 \mathrm{~B}$ & $14.6 \mathrm{~A}$ & $2.1 \mathrm{~A}$ & $1.6 \mathrm{AB}$ \\
\hline Mineral $\mathrm{PK}^{1}$ & $0.57 \mathrm{~A}$ & $108.8 \mathrm{~A}$ & $18.6 \mathrm{~A} \mathrm{~B}$ & $19.4 \mathrm{~B}$ & $2.0 \mathrm{~A}$ & $2.1 \mathrm{~B}$ \\
\hline Mineral NPK ${ }^{2}$ & $0.84 \mathrm{C}$ & $94.8 \mathrm{~B}$ & $18.8 \mathrm{AB}$ & $13.6 \mathrm{~A}$ & $1.8 \mathrm{~B}$ & $1.3 \mathrm{~A}$ \\
\hline Cattle slurry $^{3}$ & $0.67 \mathrm{~B}$ & $106.1 \mathrm{~A}$ & $19.7 \mathrm{C}$ & $13.7 \mathrm{~A}$ & $2.1 \mathrm{~A}$ & $1.5 \mathrm{~A}$ \\
\hline Sewage sludge ${ }^{3}$ & $0.57 \mathrm{~A}$ & $112.0 \mathrm{~A}$ & $18.0 \mathrm{~A}$ & $11.8 \mathrm{~A}$ & $2.0 \mathrm{~A}$ & $1.3 \mathrm{~A}$ \\
\hline \multicolumn{7}{|c|}{ After vegetative period } \\
\hline 0 & - & $46.7 \mathrm{~A}$ & $18.6 \mathrm{~A}$ & $6.2 \mathrm{AB}$ & $0.9 \mathrm{~A}$ & $0.3 \mathrm{AB}$ \\
\hline Mineral PK & - & $49.7 \mathrm{~A}$ & $18.4 \mathrm{~A}$ & $9.5 \mathrm{C}$ & $0.9 \mathrm{~A}$ & $0.5 \mathrm{C}$ \\
\hline Mineral NPK & - & $52.0 \mathrm{~A}$ & $18.1 \mathrm{~A}$ & $4.9 \mathrm{~A}$ & $1.0 \mathrm{~A}$ & $0.2 \mathrm{~A}$ \\
\hline Cattle slurry & - & $52.6 \mathrm{~A}$ & $20.1 \mathrm{~B}$ & $7.3 \mathrm{~B}$ & $1.1 \mathrm{~A}$ & $0.4 \mathrm{BC}$ \\
\hline Sewage sludge & - & $54.6 \mathrm{~A}$ & $18.6 \mathrm{~A}$ & $5.2 \mathrm{~A}$ & $1.0 \mathrm{~A}$ & $0.3 \mathrm{~A}$ \\
\hline
\end{tabular}

Notes. ${ }^{1}$ - mean of treatments $\mathrm{N}_{0} \mathrm{P}_{30} \mathrm{~K}_{60}$ and $\mathrm{N}_{0} \mathrm{P}_{60} \mathrm{~K}_{120} ;{ }^{2}$ - mean of treatments $\mathrm{N}_{60} \mathrm{P}_{30} \mathrm{~K}_{60}, \mathrm{~N}_{120} \mathrm{P}_{60} \mathrm{~K}_{120}$ and $\mathrm{N}_{180} \mathrm{P}_{60} \mathrm{~K}_{120} ;{ }^{3}-$ mean of treatment $\mathrm{N}_{60-180^{\circ}}$. Within the same column, values with different uppercase letters are significantly different $(P<0.05)$.

The difference in $\mathrm{N}$ leaching between organic and mineral treatments appeared in all experimental years only in the middle of the vegetative period, from June-August (data not presented). This could have been due to the higher organic matter decomposition rate in organic fertilizer treatments induced by the higher soil temperatures in the summer period. Bergström et al. (2008) have noted that lower $\mathrm{N}$ use efficiency in the organically fertilized treatments could have been caused by the poor synchronicity between mineralisation of $\mathrm{N}$ from the organic sources and crop $\mathrm{N}$ demand creating favourable conditions for leaching. But our research showed that the $\mathrm{N}$ from organic fertilizers leaches also at the times when plant growth is intensive and plant $\mathrm{N}$ demand is high. This result points to the possibility that a big part of $\mathrm{N}$ from organic matter leaches even before it mineralizes. Previously the same conclusion has been drawn in the review by Kessel van et al. (2009), who claim that the amount of $\mathrm{N}$ lost as dissolved organic nitrogen can be as high as one-third of the leaching losses observed for $\mathrm{NO}_{3}-\mathrm{N}$. Based on the total $\mathrm{N}$ that we determined from the leachate in our experiment it is not possible to determine the form of $\mathrm{N}$ in which it appeared.

Nitrogen leaching in both organic treatments was similar $(P>0.05)$ (Table 1$)$. From the standpoint of slurry application method we found that in three-year average $\mathrm{N}$ leaching was significantly $(P<0.05)$ less when slurry had been injected compared to spreading, indicating that $\mathrm{N}$ in the slurry was more readily available for plants when it had been injected (Tampere, 2012). Nitrogen leaching from treatments where $\mathrm{N}$ fertilizers were not used (PK and control) was significantly $(P<0.05)$ higher compared to mineral NPK and similar to leaching in organic treatments. All these treatments were characterized by the lower yield and higher water percolation (Table 1). Nitrogen in the leachate of the unfertilized control treatment points to the availability of substantial amounts of $\mathrm{N}$ in the soil. Similarly to Schröder et al. (2010) we assume that this nitrogen must have originated from the earlier organic inputs. It has been found that non-controllable factors such as mineralization of soil organic matter have a tremendous effect on nitrate loadings in drainage water (Adomaitis et al., 2008). Our results also suggest the possibility that great amount of $\mathrm{N}$ may have leached in organic form, which explains why it was not taken up by plants.

The interaction between fertilizer type and sward type on $\mathrm{N}$ leaching was not significant $(P=0.08)$. The only exception was the effect of mineral NPK and PK fertilizer on $\mathrm{N}$ leaching, which was slightly varying between swards. Differently from grass-only and grasslucerne sward, where $\mathrm{N}$ leaching was by $0.4-0.5 \mathrm{~g} \mathrm{~m}^{-2} \mathrm{~N}$ higher in PK treatments, in grass-clover sward leaching was by $0.2 \mathrm{~g} \mathrm{~m}^{-2} \mathrm{~N}$ higher in NPK treatment. This was caused by the much higher grass-clover sward yield in PK compared to NPK treatment, which consequently lowered water percolation. Slurry injection reduced $\mathrm{N}$ leaching in all swards, but significantly $(P<0.05)$ effective it was in grass-clover and grass-lucerne sward compared to surface spreading (Tampere, 2012). In all experimental years nitrogen leaching was lower when mineral NPK fertilizer had been used (Table 2). The difference in $\mathrm{N}$ leaching between NPK and cattle slurry treatment stayed the same or even decreased slightly throughout the experiment, but between NPK and sewage sludge treatment it increased. This shows that the impact of organic fertilizers on $\mathrm{N}$ leaching changed differently throughout the experimental period. We speculate that this may have been caused by the greater amount of organic matter applied with sewage sludge (data not shown), which decomposed in the soil and contributed to $\mathrm{N}$ leaching. Our results showed also that the yield difference between treatments was greater every year between NPK and sewage sludge compared to NPK and cattle slurry, indicating that the $\mathrm{N}$ in sewage sludge was not so well taken up by plants compared to cattle slurry. 
Table 2. Nitrogen (N) and potassium (K) leaching in different experimental years depending on used fertilizer type

\begin{tabular}{|c|c|c|c|c|c|c|c|c|c|}
\hline \multirow[b]{2}{*}{$\begin{array}{l}\text { Fertilizer } \\
\text { type }\end{array}$} & \multicolumn{3}{|c|}{$1^{\text {st }}$ year } & \multicolumn{3}{|c|}{$2^{\text {nd }}$ year } & \multicolumn{3}{|c|}{$3^{\text {rd }}$ year } \\
\hline & $\begin{array}{l}\text { vegetative } \\
\text { period }\end{array}$ & $\begin{array}{c}\text { after } \\
\text { vegetative } \\
\text { period }\end{array}$ & total & $\begin{array}{l}\text { vegetative } \\
\text { period }\end{array}$ & $\begin{array}{c}\text { after } \\
\text { vegetative } \\
\text { period }\end{array}$ & total & $\begin{array}{l}\text { vegetative } \\
\text { period }\end{array}$ & $\begin{array}{c}\text { after } \\
\text { vegetative } \\
\text { period }\end{array}$ & total \\
\hline \multicolumn{10}{|c|}{$\mathrm{Ng} \mathrm{m}^{-2}$} \\
\hline 0 & $2.45 \mathrm{Aba}$ & $0.31 \mathrm{ABa}$ & $2.75 \mathrm{ABa}$ & $2.07 \mathrm{Aab}$ & $1.04 \mathrm{ABb}$ & $3.12 \mathrm{Aba}$ & $1.78 \mathrm{Ab}$ & $1.46 \mathrm{Ac}$ & $3.24 \mathrm{ABa}$ \\
\hline Mineral $\mathrm{PK}^{1}$ & $2.40 \mathrm{ABa}$ & $0.28 \mathrm{Aa}$ & $2.68 \mathrm{Aa}$ & $1.97 \mathrm{Ab}$ & $1.04 \mathrm{Ab}$ & $3.01 \mathrm{ABab}$ & $1.52 \mathrm{ABc}$ & $1.67 \mathrm{ABc}$ & $3.19 \mathrm{ABb}$ \\
\hline Mineral NPK ${ }^{2}$ & $2.26 \mathrm{Aa}$ & $0.30 \mathrm{Aa}$ & $2.56 \mathrm{Aa}$ & $1.61 \mathrm{Bb}$ & $1.14 \mathrm{ABb}$ & $2.74 \mathrm{Aab}$ & $1.33 \mathrm{Bb}$ & $1.66 \mathrm{ABc}$ & $2.99 \mathrm{Bb}$ \\
\hline Cattle slurry $^{3}$ & $2.63 \mathrm{Ba}$ & $0.37 \mathrm{Ba}$ & $3.00 \mathrm{Ba}$ & $1.88 \mathrm{Ab}$ & $1.22 \mathrm{Bb}$ & $3.11 \mathrm{Ba}$ & $1.60 \mathrm{Ac}$ & $1.82 \mathrm{ABc}$ & $3.42 \mathrm{Ab}$ \\
\hline Sewage sludge ${ }^{3}$ & $2.44 \mathrm{ABa}$ & $0.33 \mathrm{ABa}$ & $2.77 \mathrm{ABa}$ & $1.82 \mathrm{ABb}$ & $1.11 \mathrm{ABb}$ & $2.92 \mathrm{Aba}$ & $1.76 \mathrm{Ab}$ & $1.88 \mathrm{Bc}$ & $3.64 \mathrm{Ab}$ \\
\hline \multicolumn{10}{|c|}{$\mathrm{K} \mathrm{g} \mathrm{m}^{-2}$} \\
\hline 0 & $2.66 \mathrm{ABa}$ & $0.26 \mathrm{Aa}$ & $2.92 \mathrm{ABa}$ & $1.40 \mathrm{ABb}$ & $0.31 \mathrm{ABa}$ & $1.72 \mathrm{Ab}$ & $0.48 \mathrm{ABCb}$ & $0.27 \mathrm{ABa}$ & $0.75 \mathrm{ABb}$ \\
\hline Mineral PK & $2.94 \mathrm{Ba}$ & $0.28 \mathrm{Aa}$ & $3.21 \mathrm{Ba}$ & $2.04 \mathrm{Bb}$ & $0.59 \mathrm{Cb}$ & $2.64 \mathrm{Ba}$ & $0.97 \mathrm{Cc}$ & $0.59 \mathrm{Bb}$ & $1.56 \mathrm{Bb}$ \\
\hline Mineral NPK & $2.21 \mathrm{Aa}$ & $0.24 \mathrm{Aa}$ & $2.45 \mathrm{Aa}$ & $0.96 \mathrm{Ab}$ & $0.30 \mathrm{Aa}$ & $1.27 \mathrm{Ab}$ & $0.28 \mathrm{ABc}$ & $0.16 \mathrm{Aa}$ & $0.45 \mathrm{Ac}$ \\
\hline Cattle slurry & $2.27 \mathrm{Aa}$ & $0.26 \mathrm{Aa}$ & $2.55 \mathrm{Aa}$ & $1.18 \mathrm{Ab}$ & $0.47 \mathrm{BCb}$ & $1.65 \mathrm{Ab}$ & $0.60 \mathrm{BCc}$ & $0.44 \mathrm{Bb}$ & $1.04 \mathrm{Bc}$ \\
\hline Sewage sludge & $2.21 \mathrm{Aa}$ & $0.26 \mathrm{Aab}$ & $2.47 \mathrm{Aa}$ & $1.03 \mathrm{Ab}$ & $0.34 \mathrm{Ab}$ & $1.38 \mathrm{Ab}$ & $0.22 \mathrm{Ac}$ & $0.18 \mathrm{Aa}$ & $0.37 \mathrm{Ac}$ \\
\hline
\end{tabular}

Notes. ${ }^{1}$ - mean of treatments $\mathrm{N}_{0} \mathrm{P}_{30} \mathrm{~K}_{60}$ and $\mathrm{N}_{0} \mathrm{P}_{60} \mathrm{~K}_{120} ;{ }^{2}-$ mean of treatments $\mathrm{N}_{60} \mathrm{P}_{30} \mathrm{~K}_{60}, \mathrm{~N}_{120} \mathrm{P}_{60} \mathrm{~K}_{120}$ and $\mathrm{N}_{180} \mathrm{P}_{60} \mathrm{~K}_{120} ;{ }^{3}-$ mean of treatment $\mathrm{N}_{60-180}$. Within the same row, values with different lowercase letters are significantly different $(P<0.05)$; within the same column, values with different uppercase letters are significantly different $(P<0.05)$.

After vegetative period, average $\mathrm{N}$ leaching increased with every experimental year and it was similar between all fertilizer treatments $(P>0.05)$ (Table 2). Similarly to vegetative period, it depended most on the amount of water percolation, but in addition also on $\mathrm{N}$ concentration in the leachate (Tampere et al., 2014). With sward age the difference in leaching between mineral and both organic fertilizer treatments increased. Nutrients in organic fertilizers mineralize over a longer period of time and increase leaching. This occurs especially after vegetative period when plant nutrient uptake is restricted. Higher organic matter application amount with sewage sludge in the vegetative period compared to cattle slurry impacted $\mathrm{N}$ leaching from sewage sludge treatment also after vegetative period.

The total (vegetative + after vegetative period) $\mathrm{N}$ leaching averaged over three-year experimental period was significantly $(P<0.05)$ the lowest when using mineral NPK fertilizer $\left(2.74 \mathrm{~g} \mathrm{~m}^{-2} \mathrm{~N}\right)$ compared to cattle slurry $\left(3.14 \mathrm{~g} \mathrm{~m}^{-2} \mathrm{~N}\right)$ and sewage sludge $\left(3.04 \mathrm{~g} \mathrm{~m}^{-2} \mathrm{~N}\right)$. From PK treatment $\left(2.93 \mathrm{~g} \mathrm{~m}^{-2} \mathrm{~N}\right)$ and control $\left(3.01 \mathrm{~g} \mathrm{~m}^{-2}\right.$ N) it did not vary.

$N$ leaching during and after vegetative period depending on $N$ rate used. In the vegetative period, averaged over three-year period fertilizer $\mathrm{N}$ rate used had significant $(P<0.05)$ influence on $\mathrm{N}$ leaching. It was significantly the lowest when the highest $\left(180 \mathrm{~kg} \mathrm{ha}^{-1}\right) \mathrm{N}$ rate was applied compared to $\mathrm{N}$ rate $60 \mathrm{~kg} \mathrm{ha}^{-1}$ (Table 3 ). The difference was significant $(P<0.05)$ even compared to control treatment where fertilizers had not been used. This relationship was valid only as an average of all fertilizer treatments. For each individual treatment it was not statistically significant $(P>0.05)$ due to the high variation in leaching within each fertilizer type and $\mathrm{N}$ rate used caused by variable weather conditions in different experimental years. Only the use of sewage sludge at rate
$180 \mathrm{~kg} \mathrm{ha}^{-1}$ reduced $\mathrm{N}$ leaching significantly $(P<0.05)$ when compared to $\mathrm{N}$ rates 60 and $120 \mathrm{~kg} \mathrm{ha}^{-1}$. Nitrogen rate used was positively correlated $(P<0.05)$ with sward yield, which in turn was in negative correlation $(P<0.05)$ with $\mathrm{N}$ leaching. Our results are in accordance with the results of Schröder et al. (2010), who showed that until the yield increases with increasing $\mathrm{N}$ rate and therefore $\mathrm{N}$ use efficiency is high, $\mathrm{N}$ rate has reducing effect on its leaching. From this result it is possible to conclude that $\mathrm{N}$ leaching can be reduced by keeping the grassland high-yielding.

Leaching at different $\mathrm{N}$ rates used between different fertilizers did not vary at $\mathrm{N}$ rates 120 and $180 \mathrm{~kg} \mathrm{ha}^{-1}$. As an only exception at $\mathrm{N}$ rate $60 \mathrm{~kg} \mathrm{ha}^{-1}$ leaching was decreased significantly $(P<0.05)$ when using mineral NPK compared to organic fertilizers (data not shown). It shows similarly to Watson and Younie (1995) that $\mathrm{N}$ leaching does not depend so much on the $\mathrm{N}$ source, but rather on its amount.

The interaction between $\mathrm{N}$ rate used and sward type on $\mathrm{N}$ leaching was significant $(P<0.05)$. In grassonly sward it decreased significantly $(P<0.05)$ with higher $\mathrm{N}$ rates, but in grass-clover sward the decrease in leaching was insignificant $(P>0.05)$ (Table 4). Grassonly sward yield increased together with $\mathrm{N}$ rate, but in grass-clover sward $\mathrm{N}$ rates above $120 \mathrm{~kg} \mathrm{ha}^{-1}$ led to white clover disappearance from the sward. The simultaneous increase in grass ratio compensated for its decline but did not increase the yield remarkably. When comparing slurry application methods at $\mathrm{N}$ rates used, the difference in $\mathrm{N}$ leaching was statistically significant only in grass sward, where leaching was significantly lower with slurry injection at $\mathrm{N}$ rate $180 \mathrm{~kg} \mathrm{ha}^{-1}$ (Tampere, 2012). $\mathrm{N}$ rate affected $\mathrm{N}$ leaching only in the vegetative period. After vegetative period leaching between different $\mathrm{N}$ rates used did not vary $(P>0.05)$ and the amounts 
Table 3. Average yields and amounts of percolated water, flow-weighted average nitrogen (N) and potassium (K) concentrations in the leachate, and average amounts of leached $\mathrm{N}$ and $\mathrm{K}$ depending on used $\mathrm{N}$ rate during and after the vegetative period (averaged for the three-year period)

\begin{tabular}{|c|c|c|c|c|c|c|}
\hline $\begin{array}{l}\mathrm{N} \text { rate } \\
\mathrm{kg} \mathrm{ha}^{-1}\end{array}$ & $\begin{array}{c}\text { Dry matter } \\
\text { yield } \\
\mathrm{kg} \mathrm{m}^{-2}\end{array}$ & $\begin{array}{c}\text { Amount of } \\
\text { percolated water } \\
\mathrm{L} \mathrm{m}^{-2}\end{array}$ & $\begin{array}{c}\mathrm{N} \text { content } \\
\text { in leachate } \\
\mathrm{mg} \mathrm{L}^{-1}\end{array}$ & $\begin{array}{c}\mathrm{K} \text { content } \\
\text { in leachate } \\
\mathrm{mg} \mathrm{L}^{-1}\end{array}$ & $\begin{array}{c}\text { Amount of } \\
\text { leached N } \\
\mathrm{g} \mathrm{m}^{-2}\end{array}$ & $\begin{array}{l}\text { Amount of } \\
\text { leached } \mathrm{K} \\
\mathrm{g} \mathrm{m}^{-2}\end{array}$ \\
\hline \multicolumn{7}{|c|}{ During vegetative period } \\
\hline 0 & $0.44 \mathrm{~A}$ & $113.4 \mathrm{~A}$ & $18.9 \mathrm{~A}$ & $14.6 \mathrm{~A}$ & $2.1 \mathrm{~A}$ & $1.6 \mathrm{~A}$ \\
\hline 60 & $0.60 \mathrm{~B}$ & $110.5 \mathrm{~A}$ & $19.4 \mathrm{~A}$ & $13.4 \mathrm{~A}$ & $2.1 \mathrm{~A}$ & $1.5 \mathrm{~A}$ \\
\hline 120 & $0.70 \mathrm{C}$ & $107.1 \mathrm{~A}$ & $18.7 \mathrm{~A}$ & $12.6 \mathrm{~A}$ & $2.0 \mathrm{AB}$ & $1.4 \mathrm{~A}$ \\
\hline 180 & $0.75 \mathrm{C}$ & $96.8 \mathrm{~B}$ & $19.2 \mathrm{~A}$ & $12.4 \mathrm{~A}$ & $1.8 \mathrm{~B}$ & $1.2 \mathrm{~A}$ \\
\hline \multicolumn{7}{|c|}{ After vegetative period } \\
\hline 0 & - & $46.7 \mathrm{~A}$ & $18.6 \mathrm{~A}$ & $6.2 \mathrm{~A}$ & $0.9 \mathrm{~A}$ & $0.3 \mathrm{~A}$ \\
\hline 60 & - & $51.5 \mathrm{~A}$ & $19.1 \mathrm{~A}$ & $5.8 \mathrm{~A}$ & $1.0 \mathrm{~A}$ & $0.3 \mathrm{~A}$ \\
\hline 120 & - & $53.5 \mathrm{~A}$ & $19.6 \mathrm{~A}$ & $5.9 \mathrm{~A}$ & $1.0 \mathrm{~A}$ & $0.3 \mathrm{~A}$ \\
\hline 180 & - & $53.8 \mathrm{~A}$ & $19.1 \mathrm{~A}$ & $6.3 \mathrm{~A}$ & $1.0 \mathrm{~A}$ & $0.3 \mathrm{~A}$ \\
\hline
\end{tabular}

Note. Within the same column, values with different uppercase letters are significantly different $(P<0.05)$.

of percolated water and $\mathrm{N}$ content in the leachate did not vary either (Table 3 ). This shows that $\mathrm{N}$ leaching after vegetative period is not impacted by the amounts of $\mathrm{N}\left(60-180 \mathrm{~kg} \mathrm{ha}^{-1}\right)$ applied to the grassland during vegetative period. It does not depend on the source of $\mathrm{N}$ used either.

Table 4. Average amounts of leached nitrogen (N) in different swards during vegetative period (averaged for the three-year period)

\begin{tabular}{ccc}
\hline $\begin{array}{c}\mathrm{N} \text { rate } \\
\mathrm{kg} \mathrm{ha}^{-1}\end{array}$ & $\begin{array}{c}\text { Dry matter yield } \\
\mathrm{kg} \mathrm{m}^{-2}\end{array}$ & $\begin{array}{c}\text { Amount of leached N } \\
\mathrm{g} \mathrm{m}^{-2}\end{array}$ \\
\hline \multicolumn{3}{c}{ Grass-only sward } \\
60 & $0.20 \mathrm{~A}$ & $2.40 \mathrm{~A}$ \\
120 & $0.40 \mathrm{~B}$ & $2.40 \mathrm{~A}$ \\
180 & $0.50 \mathrm{BC}$ & $2.15 \mathrm{AB}$ \\
\hline \multicolumn{3}{c}{$0.59 \mathrm{D}$} \\
\hline 0 & Grass-clover sward \\
60 & $0.64 \mathrm{~A}$ & $2.01 \mathrm{~B}$ \\
120 & $0.80 \mathrm{~B}$ & $1.75 \mathrm{~A}$ \\
180 & $0.83 \mathrm{~B}$ & $1.69 \mathrm{~A}$ \\
\hline
\end{tabular}

Note. Within the same column, values with different uppercase letters are significantly different $(P<0.05)$.

The three-year average total $\mathrm{N}$ leaching was significantly $(P<0.05)$ the lowest at $\mathrm{N}$ rate 180 $\left(2.88 \mathrm{~g} \mathrm{~m}^{-2} \mathrm{~N}\right)$ compared to $\mathrm{N} 60\left(3.13 \mathrm{~g} \mathrm{~m}^{-2} \mathrm{~N}\right)$. It did not differ from $\mathrm{N}$ leaching at $\mathrm{N} 120\left(3.05 \mathrm{~g} \mathrm{~m}^{-2} \mathrm{~N}\right)$ and control $\left(3.01 \mathrm{~g} \mathrm{~m}^{-2} \mathrm{~N}\right)$. Total $\mathrm{N}$ leaching at $\mathrm{N}$ rates 60 and 120 was significantly $(P<0.05)$ lower with mineral NPK fertilizer compared to both organic fertilizers, at N180 it was significantly lower only compared to cattle slurry treatment (data not shown).

Potassium (K) leaching during and after vegetative period depending on fertilizer type used. In our experiment $\mathrm{K}$ leaching losses were lower when compared to $\mathrm{N}$. The impact of fertilizer type on $\mathrm{K}$ leaching was small (Table 1). When comparing $\mathrm{K}$ leaching between mineral NPK and both organic treatments then in threeyear average they were similar $(P>0.05)$ although in all experimental years $\mathrm{K}$ leaching from cattle slurry treatment was slightly higher than in NPK and sewage sludge treatments. Higher K leaching from the treatment with cattle slurry when compared to sewage sludge was apparently due to the more narrow $\mathrm{N}: \mathrm{K}$ ratio in the applied cattle slurry with one split application (1:1.2 in three-year average) compared to sewage sludge (1:0.1 in three-year average) (Table 1 in Tampere et al., 2014) as the $\mathrm{K}$ application amounts with organic fertilizers in our experiment were not standardized. With mineral NPK fertilizer the $\mathrm{K}$ amount applied was more balanced with $\mathrm{N}$ (N:K ratio 1-1.5:1 in three-year average depending on $\mathrm{N}$ and $\mathrm{K}$ rate used) compared to cattle slurry, reducing $\mathrm{K}$ leaching more efficiently. The impact of mineral NPK fertilizer, cattle slurry and sewage sludge on K leaching was similar in all three types of swards (data not shown). In case of cattle slurry the $\mathrm{K}$ leaching even did not depend $(P>0.05)$ on slurry application method (Tampere, 2012).

In three-year average the highest $(P<0.05) \mathrm{K}$ leaching in vegetative period occurred with the use of mineral PK fertilizer (Table 1). The reason for it was the lack of $\mathrm{N}$ in this treatment, as it is known that $\mathrm{N}$ controls plants $\mathrm{K}$ assimilation (Alfaro et al., 2003). In grassonly and grass-lucerne swards $\mathrm{K}$ leaching when using PK fertilizer was significantly $(P<0.05)$ the highest (3.18 and $3.01 \mathrm{~g} \mathrm{~m}^{-2} \mathrm{~K}$, accordingly) among fertilizer treatments, in grass-clover sward it was significantly $(P<0.05)$ lower $\left(0.44 \mathrm{~g} \mathrm{~m}^{-2} \mathrm{~K}\right)$ compared to other swards and it did not vary from other fertilizer treatments (data not shown). This was due to the symbiotically fixed $\mathrm{N}$ in grass-clover sward, which increased soil plant available $\mathrm{N}$ content which in turn increased $\mathrm{K}$ uptake by plants. This effect did not appear in grass-lucerne sward due to the low percentage of lucerne in the sward.

Potassium leaching from unfertilized control treatment was similar $(P>0.05)$ to that from mineral NPK and organic fertilizers treatments (Table 1). Leaching from that treatment was probably caused by the leaching of initial soil $\mathrm{K}$, as $\mathrm{K}$ leaching was mainly determined by its concentration in the leachate (Tampere et al., 2014). 
In all experimental years during the vegetative period $\mathrm{K}$ leaching was the highest from PK treatment. The difference in K leaching between NPK and cattle slurry treatment increased with experimental years, while between NPK and sewage sludge treatment it did not change greatly or even decreased slightly (Table 2). Slower reduction in leaching from cattle slurry-fertilized sward occurred due to the accumulation of $\mathrm{K}$ in the soil throughout the experiment due to its narrow $\mathrm{N}$ : $\mathrm{K}$ ratio when compared to sewage sludge.

After vegetative period, three-year average highest $\mathrm{K}$ leaching occurred in the PK and cattle slurry treatments (Table 1). In the first year, $\mathrm{K}$ leaching did not vary between those treatments; differences appeared in the second and third year (Table 2). This result demonstrates that fertilizer type used had similar impact on $\mathrm{K}$ leaching during and after vegetative period. The highest leaching occurred from the treatments where $\mathrm{K}$ was not balanced with sufficient amount of N. Our research showed also that only in PK and cattle slurry treatments $\mathrm{K}$ leaching with sward age increased significantly $(P<0.05)$. In other treatments, including the control, $\mathrm{K}$ leaching was similar and with sward age it stayed the same or even decreased slightly. The total $\mathrm{K}$ leaching averaged over the three-year period depending on fertilizer type used was significantly the highest in PK treatment $\left(2.57 \mathrm{~g} \mathrm{~m}^{-2}\right.$ $\mathrm{K})$ compared to mineral NPK $\left(1.51 \mathrm{~g} \mathrm{~m}^{-2} \mathrm{~K}\right)$, cattle slurry $\left(1.85 \mathrm{~g} \mathrm{~m}^{-2} \mathrm{~N}\right)$ and sewage sludge $\left(1.56 \mathrm{~g} \mathrm{~m}^{-2} \mathrm{~K}\right)$, and also control $\left(1.93 \mathrm{~g} \mathrm{~m}^{-2} \mathrm{~K}\right)$. Among other treatments $\mathrm{K}$ leaching did not vary.

$K$ leaching during and after vegetative period depending on $N$ rate used. Three-year average $\mathrm{K}$ leaching between different $\mathrm{N}$ rates used was not significantly $(P$ $>0.05)$ different, although there was a tendency that increasing $\mathrm{N}$ rate reduced $\mathrm{K}$ leaching slightly during the vegetative period (Table 3 ). Although not significantly ( $P$ $>0.05$ ), but $\mathrm{K}$ leaching was the highest when no $\mathrm{N}$ was applied throughout the experimental period (Table 5), where it was probably controlled by the soil K content, as was indicated also by the highest $\mathrm{K}$ content in the leachate. The interaction between $\mathrm{N}$ rate used and fertilizer type on $\mathrm{K}$ leaching was insignificant $(P=0.94)$. In three-year average, $\mathrm{K}$ leaching after vegetative period between different $\mathrm{N}$ rates applied did not vary $(P>0.05)$.

Table 5. Nitrogen $(\mathrm{N})$ and potassium $(\mathrm{K})$ leaching in different experimental years depending on used $\mathrm{N}$ rate

\begin{tabular}{|c|c|c|c|c|c|c|c|c|c|}
\hline \multirow[b]{2}{*}{$\begin{array}{l}\mathrm{N} \text { rate } \\
\mathrm{kg} \mathrm{ha}^{-1}\end{array}$} & \multicolumn{3}{|c|}{$1^{\text {st }}$ year } & \multicolumn{3}{|c|}{$2^{\text {nd }}$ year } & \multicolumn{3}{|c|}{$3^{\text {rd }}$ year } \\
\hline & $\begin{array}{l}\text { vegetative } \\
\text { period }\end{array}$ & $\begin{array}{c}\text { after } \\
\text { vegetative } \\
\text { period }\end{array}$ & total & $\begin{array}{l}\text { vegetative } \\
\text { period }\end{array}$ & $\begin{array}{c}\text { after } \\
\text { vegetative } \\
\text { period }\end{array}$ & total & $\begin{array}{l}\text { vegetative } \\
\text { period }\end{array}$ & $\begin{array}{c}\text { after } \\
\text { vegetative } \\
\text { period }\end{array}$ & total \\
\hline \multicolumn{10}{|c|}{$\mathrm{Ng} \mathrm{m}^{-2}$} \\
\hline 0 & $2.45 \mathrm{ABa}$ & $0.31 \mathrm{Aa}$ & $2.75 \mathrm{Aa}$ & $2.07 \mathrm{Aab}$ & $1.04 \mathrm{Ab}$ & $3.12 \mathrm{ABa}$ & $1.78 \mathrm{Ab}$ & $1.46 \mathrm{Ac}$ & $3.24 \mathrm{Aa}$ \\
\hline 60 & $2.63 \mathrm{Ba}$ & $0.34 \mathrm{Aa}$ & $2.96 \mathrm{Aa}$ & $1.97 \mathrm{Ab}$ & $1.13 \mathrm{Ab}$ & $3.10 \mathrm{Bab}$ & $1.66 \mathrm{Ac}$ & $1.74 \mathrm{Bc}$ & $3.40 \mathrm{Ab}$ \\
\hline 120 & $2.49 \mathrm{ABa}$ & $0.33 \mathrm{Aa}$ & $2.82 \mathrm{Aa}$ & $1.83 \mathrm{Ab}$ & $1.20 \mathrm{Ab}$ & $3.02 \mathrm{ABa}$ & $1.57 \mathrm{Ac}$ & $1.88 \mathrm{Bc}$ & $3.44 \mathrm{Ab}$ \\
\hline 180 & $2.35 \mathrm{Aa}$ & $0.36 \mathrm{Aa}$ & $2.71 \mathrm{Aa}$ & $1.61 \mathrm{Bb}$ & $1.18 \mathrm{Ab}$ & $2.79 \mathrm{Aa}$ & $1.49 \mathrm{Ab}$ & $1.77 \mathrm{Bc}$ & $3.26 \mathrm{Ab}$ \\
\hline \multicolumn{10}{|c|}{$\mathrm{K} \mathrm{g} \mathrm{m}^{-2}$} \\
\hline 0 & $2.66 \mathrm{Aa}$ & $0.26 \mathrm{Aa}$ & $2.92 \mathrm{Aa}$ & $1.40 \mathrm{Ab}$ & $0.31 \mathrm{Aa}$ & $1.72 \mathrm{Ab}$ & $0.48 \mathrm{Ac}$ & $0.27 \mathrm{Aa}$ & $0.75 \mathrm{Ab}$ \\
\hline 60 & $2.42 \mathrm{Aa}$ & $0.25 \mathrm{Aa}$ & $2.67 \mathrm{Aa}$ & $1.27 \mathrm{Ab}$ & $0.38 \mathrm{Ab}$ & $1.65 \mathrm{Ab}$ & $0.39 \mathrm{Ac}$ & $0.26 \mathrm{Aab}$ & $0.64 \mathrm{Ac}$ \\
\hline 120 & $2.26 \mathrm{Aa}$ & $0.24 \mathrm{Aa}$ & $2.50 \mathrm{Aa}$ & $1.09 \mathrm{Ab}$ & $0.38 \mathrm{Ab}$ & $1.47 \mathrm{Ab}$ & $0.44 \mathrm{Ac}$ & $0.34 \mathrm{Aab}$ & $0.78 \mathrm{Ac}$ \\
\hline 180 & $2.10 \mathrm{Aa}$ & $0.28 \mathrm{Aa}$ & $2.41 \mathrm{Aa}$ & $0.91 \mathrm{Ab}$ & $0.44 \mathrm{Ab}$ & $1.35 \mathrm{Ab}$ & $0.46 \mathrm{Ac}$ & $0.31 \mathrm{Aab}$ & $0.79 \mathrm{Ac}$ \\
\hline
\end{tabular}

Note. Within the same row, values with different lowercase letters are significantly different $(P<0.05)$; within the same column, values with different uppercase letters are significantly different $(P<0.05)$.

Nitrogen rate used did not have significant $(P>$ $0.05)$ impact on total three-year average $\mathrm{K}$ leaching, but there was a tendency that it decreased with increasing $\mathrm{N}$ rate. Total leaching was $1.81,1.69$ and $1.60 \mathrm{~g} \mathrm{~m}^{-2} \mathrm{~K}$ accordingly with $\mathrm{N}$ rates 60,120 and $180 \mathrm{~kg} \mathrm{ha}^{-1}$. The highest $\mathrm{K}$ leaching $\left(1.93 \mathrm{~g} \mathrm{~m}^{-2} \mathrm{~K}\right)$ appeared when no fertilizers were applied.

\section{Conclusions}

1. Our results supported our hypothesis that nitrogen $(\mathrm{N})$ leaching in cut grassland depends on fertilizer type. When compared with organic fertilizers $(2.0-2.1 \mathrm{~g}$ $\mathrm{m}^{-2} \mathrm{~N}$ ), $\mathrm{N}$ leaching was less when using mineral NPK fertilizer $\left(1.8 \mathrm{~g} \mathrm{~m}^{-2} \mathrm{~N}\right)$ due to its great positive impact on grassland yield. Our results showed also that as long as the yield increases and $\mathrm{N}$ use is efficient, increasing $\mathrm{N}$ rate reduces $\mathrm{N}$ leaching. This indicates that one measure for leaching reduction can be keeping the grassland highyielding. Differences between treatments and $\mathrm{N}$ rates used appeared only in the vegetative period.

2. Potassium (K) leaching depended almost solely on the N:K ratio of applied fertilizers and increased when the ratio became narrower. The highest $\mathrm{K}$ leaching $\left(2.1 \mathrm{~g} \mathrm{~m}^{-2} \mathrm{~K}\right)$ in our experiment occurred in the treatment where no $\mathrm{N}$ had been applied with fertilizer. Similar tendency was seen also after vegetative period.

3. Leaching of $\mathrm{N}\left(2.1 \mathrm{~g} \mathrm{~m}^{-2} \mathrm{~N}\right)$ and $\mathrm{K}\left(1.6 \mathrm{~g} \mathrm{~m}^{-2}\right.$ $\mathrm{K})$ from unfertilized soil can be as high or even higher compared to soil receiving mineral or organic fertilizer, indicating that a considerable part of nutrients leaching is not connected with fertilizer use. 
4. In grassland, slurry injection at quantities optimal for sward type can be an effective method in the reduction of $\mathrm{N}$ leaching, because $\mathrm{N}$ in the slurry is thereby more available to plants.

\section{Acknowledgments}

This study was supported by the Ministry of Education and Science, Grant SF 0170052s08, and by the Ministry of Agriculture, contracts No. 3.4.-23/22 and 333.

Received 15052015

Accepted 27102015

\section{References}

Adomaitis T., Vaisvila Z., Mazvila J., Staugaitis G., Fullen M. A. 2008. Influence of mineral fertilizer on nitrogen leaching. Acta Agriculturae Scandinavica, Section B: Plant Soil Science, 58 (3): 199-207 http://dx.doi.org/10.1080/09064710701593012

Alfaro M. A., Jarvis S. C., Gregory P. J. 2003. Potassium budgets in grassland systems as affected by nitrogen and drainage. Soil Use and Management, 19 (2): 89-95 http://dx.doi.org/10.1079/SUM2002172

Alfaro M. A., Jarvis S. C., Gregory P. J. 2004. Factors affecting potassium leaching in different soils. Soil Use and Management, 20: 182-189 http://dx.doi.org/10.1079/SUM2004249

Aronsson H., Torstensson G., Bergström L. 2006. Leaching and crop uptake of $\mathrm{N}, \mathrm{P}$ and $\mathrm{K}$ from organic and conventional cropping systems on a clay soil. Soil Use and Management, 23 (1): 71-81 http://dx.doi.org/10.1111/j.1475-2743.2006.00067.x

Bergström L., Kirchmann H., Aronsson H., Torstensson G., Mattsson L. 2008. Use efficiency and leaching of nutrient in organic and conventional cropping systems in Sweden. Kirchmann H., Bergström L. (eds.). Organic crop production - ambitions and limitations, p. 143-159 http://dx.doi.org/10.1007/978-1-4020-9316-6 7

CondronL.M., CameronK.C.,DiH.J.,Clough T.J.,Forbes E. A., McLaren R. G., Silva R. G. 2000. A comparison of soil and environmental quality under organic and conventional farming systems in New Zealand. New Zealand Journal of Agricultural Research, 43 (4): 443-466 http://dx.doi.org/10.1080/00288233.2000.9513442

Gali R. K., Soupir M. L., Mostaghimi S. 2012. A comparison of nutrient losses from two simulated pastureland management scenarios. Journal of Environmental Monitoring, 14 (9): $2421-2429$

http://dx.doi.org/10.1039/c2em30390f

Hansen B., Kristensen E. S., Grant R., Høgh-Jensen H., Simmelsgaard S. E., Olesen J. E. 2000. Nitrogen leaching from conventional versus organic farming systems a systems modelling approach. European Journal of Agronomy, 13: 65-82 http://dx.doi.org/10.1016/S1161-0301(00)00060-5

Kayser M., Isselstein J. 2005. Potassium cycling and losses in grassland systems: a review. Grass and Forage Science, 60 (3): $213-224$

http://dx.doi.org/10.1111/j.1365-2494.2005.00478.x
Kessel van C., Clough T., Groenigen van J. W. 2009. Dissolved organic nitrogen: an overlooked pathway of nitrogen loss. Journal of Environmental Quality, 38: 393-401 http://dx.doi.org/10.2134/jeq2008.0277

Kirchmann H., Bergström L. 2001. Do organic farming practices reduce nitrate leaching? Do organic farming practices? Communications in Soil Science and Plant Analysis, 32 (7-8): 997-1028 http://dx.doi.org/10.1081/CSS-100104101

Kirchmann H., Johnston J. A. E., Bergström L. F. 2002. Possibilities for reducing nitrate leaching from agricultural land. Ambio, 31 (5): 404-408 http://dx.doi.org/10.1579/0044-7447-31.5.404

Knudsen M. T., Kristensen I. B. S., Berntsen J., Petersen B. M., Kristensen E. S. 2006. Estimated N leaching losses for organic and conventional farming in Denmark. The Journal of Agricultural Science, 144 (2): 135-149 http://dx.doi.org/10.1017/S0021859605005812

Laegreid M., Bockman O. C., Karrstad O. 1999. Concerns relating to fertiliser use. Agriculture, fertiliser and the environment. Wallingford, UK, p. 158-161

Malhi S. S., Brandt S. A., Ulrich D., Lemke R., Gill K. S. 2002. Accumulation and distribution of nitrate - nitrogen and extractable phosphorus in the soil profile under various alternative cropping systems. Journal of Plant Nutrition, 25 (11): 2499-2520 http://dx.doi.org/10.1081/PLN-120014709

Mondelaers K., Aertsens J., Huylenbroeck Van G. 2009. A metaanalysis of the differences in environmental impacts between organic and conventional farming. British Food Journal, 111 (10): 1098-1119 http://dx.doi.org/10.1108/00070700910992925

Raave H., Keres I., Kauer K., Nõges M., Rebane J., Tampere M., Loit E. 2014. The impact of activated carbon on $\mathrm{NO}_{3}{ }^{-} \mathrm{N}$, $\mathrm{NH}_{4}^{+}-\mathrm{N}, \mathrm{P}$ and $\mathrm{K}$ leaching in relation to fertilizer use. European Journal of Soil Science, 65 (1): 120-127 http://dx.doi.org/10.1111/ejss.12102

Schröder J. J., Assinck F. B. T., Uenk D., Veltof G. L. 2010. $\mathrm{N}$ leaching from cut grassland as affected by the substitution of slurry with nitrogen mineral fertilizer on two soil types. Grass and Forage Science, 65: 49-57 http://dx.doi.org/10.1111/j.1365-2494.2009.00719.x

Shepherd M. A. 1996. Factors affecting nitrate leaching from sewage sludges applied to a sandy soil in arable agriculture. Agriculture, Ecosystems and Environment, 58: 171-185 http://dx.doi.org/10.1016/0167-8809(96)01018-3

Tampere M. 2012. Impact of slurry application method on sward yield and $\mathrm{N}$ and $\mathrm{K}$ leaching from grassland. $18^{\text {th }}$ international scientific conference Research for Rural Development. Jelgava, Latvia, vol. 1, p. 38-43

Tampere M., Kauer K., Keres, I., Loit E., Selge A., Viiralt R., Raave H. 2014. Effects of sward botanical composition on nitrogen and potassium leaching in cut grassland. Zemdirbyste-Agriculture, 101 (4): 389-394 http://dx.doi.org/10.13080/z-a.2014.101.049

Ten Berge H. F. M., van der Meer H. G., Carlier L., Hofman T. B., Neeteson J. J. 2002. Limits to nitrogen use on grassland. Environmental Pollution, 118 (2): 225-238 http://dx.doi.org/10.1016/S0269-7491(01)00315-3 
Torstensson G., Aronsson H., Bergström L. 2006. Nutrient use efficiencies and leaching of organic and conventional cropping systems in Sweden. Agronomy Journal, 98 (3): 603-615

http://dx.doi.org/10.2134/agronj2005.0224

Usman K., Khan S., Ghulam S., Khan M. U., Khan N., Khan M. A., Khalil S. K. 2012. Sewage sludge: an important biological resource for sustainable agriculture and its environmental implications. American Journal of Plant Sciences, 3: 1708-1721

http://dx.doi.org/10.4236/ajps.2012.312209
Wang X., Chen T., Ge Y., Jia Y. 2008. Studies on land application of sewage sludge and its limiting factors. Journal of Hazardous Materials, 160 (2-3): 554-558 http://dx.doi.org/10.1016/j.jhazmat.2008.03.046

Watson C. A., Younie D. 1995. Nitrogen balances in organically and conventionally managed beef production systems. Pollott G. E. (ed.). Grassland into the $21^{\text {st }}$ century: challenges and opportunities, p. 197-199

Zhang F., Niu J., Zhang W., Chen X., Li C., Yuan L., Xie J. 2010. Potassium nutrition of crops under varied regimes of nitrogen supply. Plant and Soil, 335: 21-34 http://dx.doi.org/10.1007/s11104-010-0323-4

ISSN 1392-3196 / e-ISSN 2335-8947

Zemdirbyste-Agriculture, vol. 102, No. 4 (2015), p. 381-388

DOI $10.13080 / \mathrm{z}-\mathrm{a} .2015 .102 .048$

\title{
Trąšų ir azoto normų įtaka azoto bei kalio išplovimui iš šienaujamo žolyno
}

\author{
M. Tampere, K. Kauer, I. Keres, E. Loit, A. Selge, R. Viiralt, H. Raave \\ Estijos gyvybès mokslų universiteto Žemès ūkio ir aplinkos mokslų institutas
}

\begin{abstract}
Santrauka
Nors tręšimas turi teigiamos ịtakos žemès ūkio augalu produktyvumui, jo neigiamas šalutinis poveikis gali būti maisto medžiagų išplovimas. Tyrimo metu siekta ištirti trąšų rūšių ir azoto normų įtaką azoto $(\mathrm{N})$ bei kalio $(\mathrm{K})$ išplovimui iš pievos vegetacijos metu ir po jos. Trejus metus (2008-2011) minilizimetrų bandymai buvo vykdyti pievos žolynuose, tręštuose mineralinèmis NPK ir PK trąšomis, galvijų srutomis bei nuotekų dumblu, trąšų kieki apskaičiuojant pagal metinę $0,60,120$ ir $180 \mathrm{~kg} \mathrm{ha}^{-1}$ normą azoto. Azoto ir kalio išplovimas buvo matuotas kas mẻnesị visą tyrimo laikotarpị. Tyrimo rezultatai leidžia daryti išvadą, kad azoto išplaunama mažiau trę̌siant mineralinėmis NPK trą̧̌̌omis, nes jos efektyviausiai didina žolyno derlių. Kalio išplovimą iš pievos galima sumažinti trę̌iiant azoto turinčiomis trą̌somis, nes trą̌š N:K santykis turi didelę ịtaką jo išplovimo potencialui. Trą̧̌sos nèra vienintelè $\mathrm{N}$ ir $\mathrm{K}$ išplovimo priežastis. Išplovimas gali būti didelis ir iš netrę̌šo dirvožemio, priklausomai nuo šiu elementų kiekio jame. Tręšimas racionaliomis normomis srutų gali būti veiksmingas azoto išplovimo mažinimo būdas pievose.
\end{abstract}

Reikšminiai žodžiai: azotas, azoto norma, galvijų srutos, išplovimas, kalis, nuotekų dumblas. 